\title{
Pengembangan Sentra Industri Kecamatan Tempuran Berdasarkan Indeks Spesialisasi dan Konsentrasi Spasial di Kabupaten Magelang
}

\author{
Andi Panca Putra, Andri Kurniawan, Sri Rahayu Budiani \\ Masuk: 13082019 / Diterima: 21112019 / Dipublikasi: 31122019 \\ (c) 2019 Fakultas Hukum dan IImu Sosial UNDIKSHA dan IGI
}

\begin{abstract}
Industrial existence sometimes becomes a post of urban development growth. Attempt to develop industry in Tempuran district is not supported by the widespread availability of data about the small and medium industry in there. Lack of comprehensive data and information about the small industry, medium industry, and household industry in Tempuran district can cause problems. Growing industries in Tempuran district are not placed in one particular sector as industrial estate but scatter at a few villages. Industrial existence mixed up with other functions like settlement, trade, and services, also agricultural land. This study aims to analyze the spatial concentration of industrial centers in Tempuran district. The method used in this study is quantitative descriptive to identify the spatial concentration of the industrial center in Tempuran district. Result shows there are seven agglomerated industrial center in Tempuran district namely wood jamb industry center with the most significant Hirschmann-Herfindhal Index (HHI) of 0.8706, birdcage industry center with $\mathrm{HHI}$ of 0.6676, tempe industry center with $\mathrm{HHI}$ of 0.5954 , wooden furniture industry center with $\mathrm{HHI}$ of 0.5718 , besek industry center with $\mathrm{HHI}$ of 0,4867, and brick industry center with $\mathrm{HHI}$ of 0,4375. Whereas, three industrial centers are in the category of dispersion namely slondok industry center, roof tile industry center, and cob basket industry center.
\end{abstract}

Key words: Industrial Center Development; Industrial Indeks Specialization; Industrial Agglomeration

\begin{abstract}
Abstrak Keberadaan industri seringkali menjadi kutub pertumbuhan bagi perkembangan wilayah. Upaya pengembangan industri di Kecamatan Tempuran tidak didukung oleh ketersediaan data yang komprehensif mengenai industri kecil dan menengah tersebut. Minimnya ketersediaan data informasi yang komprehensif terkait industri menengah, industri kecil dan rumah tangga di Kecamatan Tempuran dapat menimbulkan permasalahan. Industri-industri yang berkembang di Kecamatan Tempuran tidak berada pada satu kawasan khusus sebagai industrial estate tetapi menyebar pada beberapa desa. Keberadaan industri bercampur dengan fungsi-fungsi lain seperti permukiman, perdagangan dan jasa, serta lahan pertanian. Penelitian ini bertujuan untuk menganalisis Konsentrasi Spasial sentra industri di Kecamatan Tempuran. Metode yang digunakan dalam penelitian ini menggunakan deskriptif kuantitatif untuk mengidentifikasi konsentrasi spasial sentra industri di Kecamatan Tempuran. Hasil penelitian menunjukan bahwa terdapat tujuh sentra industri yang teraglomerasi, yakni sentra industri kusen kayu memiliki nilai Indeks Hirschmann-Herfindhal $(\mathrm{IHH})$ terbesar dengan nilai 0,8706, Sentra industri Sangkar Burung dengan nilai Indeks IHH 0,6676, sentra industri tempe dengan nilai Indeks $\mathrm{IHH}$ 0,5954, sentra industri Mebel Kayu dengan nilai Indeks $\mathrm{IHH}$ 0,5718, sentra industri Besek dengan nilai Indeks $\mathrm{IHH}$ 0,4867 dan sentra industri batu bata dengan nilai indeks $\mathrm{IHH} 0,4375$, sedangkan sentra industri yang termasuk kategori dispersi terdapat tiga sentra, yakni, sentra industri Slondok, Sentra Industri Genteng, sentra industri Keranjang Tongkol.
\end{abstract}

Kata kunci : Pengembangan Sentra Industri; Indeks Spesialisasi Industri; Aglomerasi Industri

\section{Pendahuluan}

Dalam perkembangannya, peranan sektor pertanian dalam pembangunan

Andi Panca Putra, Andri Kurniawan, Sri Rahayu Budiani Fakultas Geografi, Universitas Gadjah Mada lumbantoruanunimed@gmail.com ekonomi di Indonesia mulai tergeser oleh peranan sektor industri manufaktur yang mengalami perkembangan pesat. Adanya pergeseran peranan sektor pertanian oleh sektor industri menyebabkan terjadinya perubahan struktur ekonomi dari 
perekonomian yang berbasis agraris menjadi perekonomian yang berbasis industri.

Secara teoritis agglomerasi mengandung dua pengertian utama. Pengertian pertama adalah proses yang dilakukan secara bersama-sama dalam melakukan mobilitas secara spasial. Pengertian kedua menunjukkan suatu bentuk lokasional, terutama bagaimana aktivitas ekonomi terkonsentrasi secara spasial (Whynne \& Hammond, 1979). Secara umum pengamatan mengenai agglomerasi diawali dengan observasi mengenai bentuk agglomerasi dan mendiskusikan mengenai proses bagaimana itu terjadi.

Secara terminologi terdapat perbedaan makna antara spesialisasi dan konsentrasi. Spesialisasi dapat didefinisikan sebagai distribusi share industri dari suatu wilayah. Sedangkan Konsentrasi dapat didefinisikan sebagai regional share yang menunjukkan distribusi lokasional dari suatu industri. Pada wilayah yang terspesialisasi, konsentrasi menunjukkan tingkatan aktivitas dan distribusi lokasional dari industri pada wilayah tersebut, dimana pada umumnya aktivitas ekonomi lebih terkonsentrasi wilayah core (inti) daripada periphery (pinggiran).

Kabupaten Magelang mengalami perkembangan di sektor industri, Keberadaan industri menengah, industri kecil dan rumah tangga dapat menciptakan lapangan pekerjaan, sehingga dianggap sebagai pendorong peningkatan perekonomian. Perlu adanya upaya lebih lanjut demi pengembangan industri di Kabupaten Magelang. Upaya pengembangan industri di Kabupaten Magelang tidak didukung oleh ketersediaan data yang komprehensif mengenai industri kecil dan menengah tersebut. Minimnya ketersediaan data informasi yang komprehensif terkait industri menengah, industri kecil dan rumah tangga di Kabupaten Magelang dapat menimbulkan permasalahan,

Kecamatan Tempuran sebagai Kawasan Peruntukan Industri (KPI) ditetapkan berdasarkan Peraturan Daerah Nomor 5 Tahun 2011 tentang Rencana Tata Ruang Wilayah (RTRW) Kabupaten Magelang Tahun 2010-2030. Beberapa pertimbangan dalam penetapan kawasan peruntukan industri di Kecamatan Tempuran adalah lokasi yang strategis karena dilalui jalan propinsi dan kondisi tanah yang relatif datar. Di samping itu, Kecamatan Tempuran berada cukup dekat dengan Kota Magelang sebagai lokasi awal berdirinya beberapa industri yang sekarang berada di Tempuran.

Dalam perkembangannya, kegiatan industri seringkali menimbulkan ketidakpastian dari segi ekonomi. Gambaran mengenai kondisi lokasi industri. Magelang mempunyai visi pembangunan yang bertumpu pada sektor Industri, pertanian, dan pariwisata.

Berkenaan dengan pentingnya peran industri dalam kaitannya menambah nilai guna maupun ekonomis, maka penting untuk dilakukan kajian terhadap kondisi spesialisasi dan konsentrasi spasial industri di Kabupaten Magelang. Dalam penelitian-penelitian sebelumnya yang pernah dilakukan oleh peneliti lain lebih banyak mengkaji tentang sebaran dan faktor penyebab kondisi spesialisasi dan konsentrasi spasial dari suatu industri (Ferdyansyah \& Santoso, 2013; Setiawan \& Sudrajat, 2019; Suhardi, 2010). Selain itu penelitian lain yang sejenis juga mengkaji hanya dari sisi karakteristik, sebaran dan pengaruhnya terhadap struktur industri di masing-masing wilayah (Pridiatama, Kurniawan, \& Sudrajat, 2019). Berkaca dari penelitian sejenis yang pernah dilakukan, maka pnelitian ini dilakukan dengan tujuan yang berbeda yakni untuk mengetahui indeks spesialisasi dan Konsentrasi spasial industri di Kabupaten Magelang. 


\section{Metode}

Penelitian tentang pengembangan sentra industri berdasarkan spesialisasi dan konsentrasi spasial menggunakan metode deskriptif dengan analisis kuantitatif. Data yang dianalisis adalah data sekunder yang bersumber dari instansi terkait seperti BPS, Bappeda, dan data dari Disperindag Kabupaten Magelang. Data yang terkumpul ditelaah lebih lanjut secara deskriptif untuk memberikan gambaran tentang indeks spesialisasi dan konsentrasi spasial dari sentra industri.

Secara lebih spesifik,penelitian dilaksanakan di Kecamatan Tempuran Kabupaten Magelang. Kecamatan Tempuran sebagai Kawasan Peruntukan Industri (KPI) ditetapkan berdasarkan Peraturan Daerah Nomor 5 Tahun 2011 tentang Rencana Tata Ruang Wilayah (RTRW) Kabupaten Magelang Tahun 2010-2030. Beberapa pertimbangan dalam penetapan kawasan peruntukan industri di Kecamatan Tempuran adalah lokasi yang strategis karena dilalui jalan propinsi dan kondisi tanah yang relatif datar. Di samping itu, Kecamatan Tempuran berada cukup dekat dengan Kota Magelang sebagai lokasi awal berdirinya beberapa industri yang sekarang berada di Tempuran.

Populasi dalam penelitian ini adalah semua sentra industri berskala mikro, kecil dan Menengah di Kecamatan Tempuran. Sedangkan penentuan sampel menggunakan snowball sampling. Hal ini berkaitan dengan tujuan serta kondisi di lapangan saat dilakukan penelitian.

\section{Hasil dan Pembahasan}

\section{Indeks spesialisasi industri Kecamatan Tempuran}

Menurut Suhardi (2010), spesialisasi industri menunjukkan bahwa aktivitas ekonomi pada suatu wilayah dikuasai oleh beberapa industri tertentu. Suatu wilayah dapat diartikan sebagai wilayah yang terspesialisasi apabila dalam sebagian kecil industri pada wilayah tersebut memiliki pangsa yang besar terhadap keseluruhan industri.

Ratnasari (2013) memperoleh temuan bahwa Penyerapan tenaga kerja industri kecil menengah (IKM) lebih unggul karena sektor IKM adalah sub sektor yang mengelola jenis-jenis industri yang berskala kecil atau menengah seperti industri rumah tangga, dan indutri skala kecil lainnya yang lebih mudah untuk dibentuk oleh masyarakat terutama masyarakat ekonomi menengah ke bawah. Meskipun pengembangan industriindustri besar dapat menyerap tenaga kerja yang banyak, tetapi untuk memasuki pasar tenaga kerja sektor industri besar, diperlukan keterampilan-keterampilan khusus yang tidak dimiliki oleh masyarakat ekonomi menengah kebawah.

Konsentrasi spasial pada industri bisa terjadi akibat adanya aglomerasi yang disebabkan oleh upaya mengurangi biaya transportasi dengan berlokasi di sekitar local demand yang besar serta upaya untuk memperoleh akses pasar yang luas. Krugman (1991) pendapat ini dapat membantu menjelaskan kenapa terjadi konsentrasi spasial pada industri kecil di Kecamatan Tempuran. Jumlah penduduk Kecamatan Tempuran dan berdekatan dengan Kabupaten Magelang sebagai pusat perekonomian merupakan pasar potensial bagi output industri kecil. Jumlah penduduk sebagai pasar potensial yang mendukung industri merupakan natural advantages wilayah yang berperan penting dalam proses aglomerasi. Pada industri kecil pekerja merupakan dari keluarga sendiri atau lingkungan sekitar. Jadi salah satu sektor industri kecil andalan Kecamatan Tempuran adalah subsektor industri batu bata dan sangkar burung.

Hasil penelitian Agustina \& Rejekiningsih (2011) menyimpulkan bahwa Subsektor IKM unggulan Kota 
Semarang berdasarkan spesialisasi tingkat kecamatan adalah subsektor industri makanan, minuman dan tembakau. Terdapat pula beberapa wilayah konsentrasi IKM di Kota
Semarang di antaranya Kecamatan Genuk dimana wilayah konsentrasi tersebut terjadi karena adanya agglomeration effect dan akses pasar yang luas seperti terlihat pada Tabel 1.

Tabel 1. Indeks Spesialiasai Sentra Industri di Kecamatan Tempuran

\begin{tabular}{clr}
\hline No & Jenis industri & S\% \\
\hline 1 & Tempe & $6,59 \%$ \\
2 & Slondok & $1,63 \%$ \\
3 & Batu bata & $21,71 \%$ \\
4 & Mebel Kayu & $4,48 \%$ \\
5 & Besek & $1,26 \%$ \\
6 & Ker. Tongkol & $6,09 \%$ \\
7 & Kusen Kayu & $1,70 \%$ \\
8 & Sangkar Burung & $13,44 \%$ \\
9 & Genteng & $6,32 \%$ \\
\hline
\end{tabular}

Sumber: BPS Kabupaten Magelang, 2018

Menurut pandangan Marshall (2003 dalam Suhardi, 2010) indeks spesialisasi industri diambil dua nilai terbesar. Berdasarkan hasil perhitungan, industri batu bata memiliki nilai indeks spesialisasi terbesar $21,71 \%$, selanjutnya sentra industri sangkar burung dengan nilai indeks spesialisasi sebesar 13,44 persen. Perkembangan sentra industri dapat didorong oleh terjadinya aglomerasi yang disebabkan oleh eksternalitas berupa knowledge spillover dan tenaga kerja yang terspesialisasi. Selain itu perkembangan industri juga didorong oleh akses pasar, baik berupa jumlah penduduk maupun sarana transportasi.

\section{Konsentrasi sentra industri}

Fenomena konsentrasi spasial dapat ditemukan pada kebanyakan negara berkembang dimana distribusi penduduk dan konsentrasi industri terkonsentrasi di kota-kota besar seperti Bangkok, New Delhi, Sao Paulo, dan Jakarta, yang menandai suatu sistem spasial berdasarkan akumulasi modal dan tenaga kerja dalam aglomerasi.

Hal tersebut juga diungkapkan oleh Sulastri (2013) menyatakan bahwa konsentrasi spasial merupakan pengelompokan setiap industri dan aktivitas ekonomi secara spasial, dimana industri tersebut berlokasi pada suatu wilayah tertentu. Konsentrasi Spasial menunjukkan share suatu wilayah dan distribusi lokasi dari suatu industri. Apabila distribusi spasial suatu industri tidak merata, dan ada wilayah yang mendominasi berlokasinya industri, maka menunjukkan bahwa industri terkonsentrasi sacara spasial di wilayah tersebut seperti terlihat pada Tabel 2.

Tabel 2. Nilai Indeks IHH Sentra Industri di Kecamatan Tempuran

\begin{tabular}{clc}
\hline No & Sentra Industri & Nilai IHH \\
\hline 1 & Tempe & 0,5954 \\
2 & Slondok & 0,2829 \\
3 & Batu bata & 0,4375 \\
4 & Mebel Kayu & 0,5718 \\
5 & Besek & 0,4867 \\
6 & Ker. Tongkol & 0,1608 \\
7 & Kusen Kayu & 0,8706 \\
8 & Sang. Burung & 0,6676 \\
9 & Genteng & 0,2935 \\
\hline
\end{tabular}

Sumber: BPS Kabupaten Magelang, 2018 
Berdasarkan Tabel 2 hasil perhitungan IHH terdapat enam sentra industri yang memiliki aglomerasi di atas 0,4375 yakni sentra industri Kusen kayu sentra industri sangkar burung dengan nilai $\mathrm{IHH}$ sebesar 0,667 , sentra industri tempe dengan nilai $\mathrm{IHH}$ sebesar 0,5954, sentra industri mebel kayu dengan nilai IHH sebesar 0,5718, sentra industri besek memiliki nilai $\mathrm{IHH}$ sebesar 0,4867 sentra industri besek, sentra industri batu bata memiliki nilai IHH sebesar 0,4375 yang menunjukan sentrasentra industri teraglomerasi.

Sementara sentra industri yang dikategorikan dispersi yang memiliki Indeks $\mathrm{IHH}$ kurang dari 0,4375 terdapat tiga sentra industri yakni, sentra industri genteng d engan nilai IHH sebesar 0,2935, sentra industri slondok memiliki nilai $\mathrm{IHH}$ sebesar 0,2829, sentra industri keranjang tongkol dengan nilai IHH sebesar 0,1608. Triamita (2012) memperoleh temuan bahwa konsentrasi regional tenaga kerja yang tinggi membuktikan bahwa UKM di
Kab/Kota di Jawa Timur memiliki peran yang lebih tinggi dalam penyerapan tenaga kerja, ini berarti UKM sebagai aktivitas basis dalam perekonomian daerah tersebut.

\section{Konsentrasi spasial sentra industri}

Menurut pakar ekonomi dunia, Marshal (dalam Suhardi, 2010) menyatakan bahwa efek dari konsentrasi spasial adalah terciptanya spesialisasi dan konsentrasi pada daerah tertetnu sehingga daerah yang memiliki spesialisasi dan terkonsentrasi terbesar adalah daerah yang memiliki konsentrasi spasial. pandangan ini sering kali disebut dengan Marshal Industrial District. Pandangan tersebut masih relevan sampai saat ini dan secara empiris masih dapat dijumpai. Berdasarkan hasil perhitungan $\mathrm{IHH}$ dan Spesialisasi dengan pendekatan pangsa tenaga kerja, konsentrasi spasial sentra industri di Kecamatan Salaman seperti terlihat pada Gambar 1.

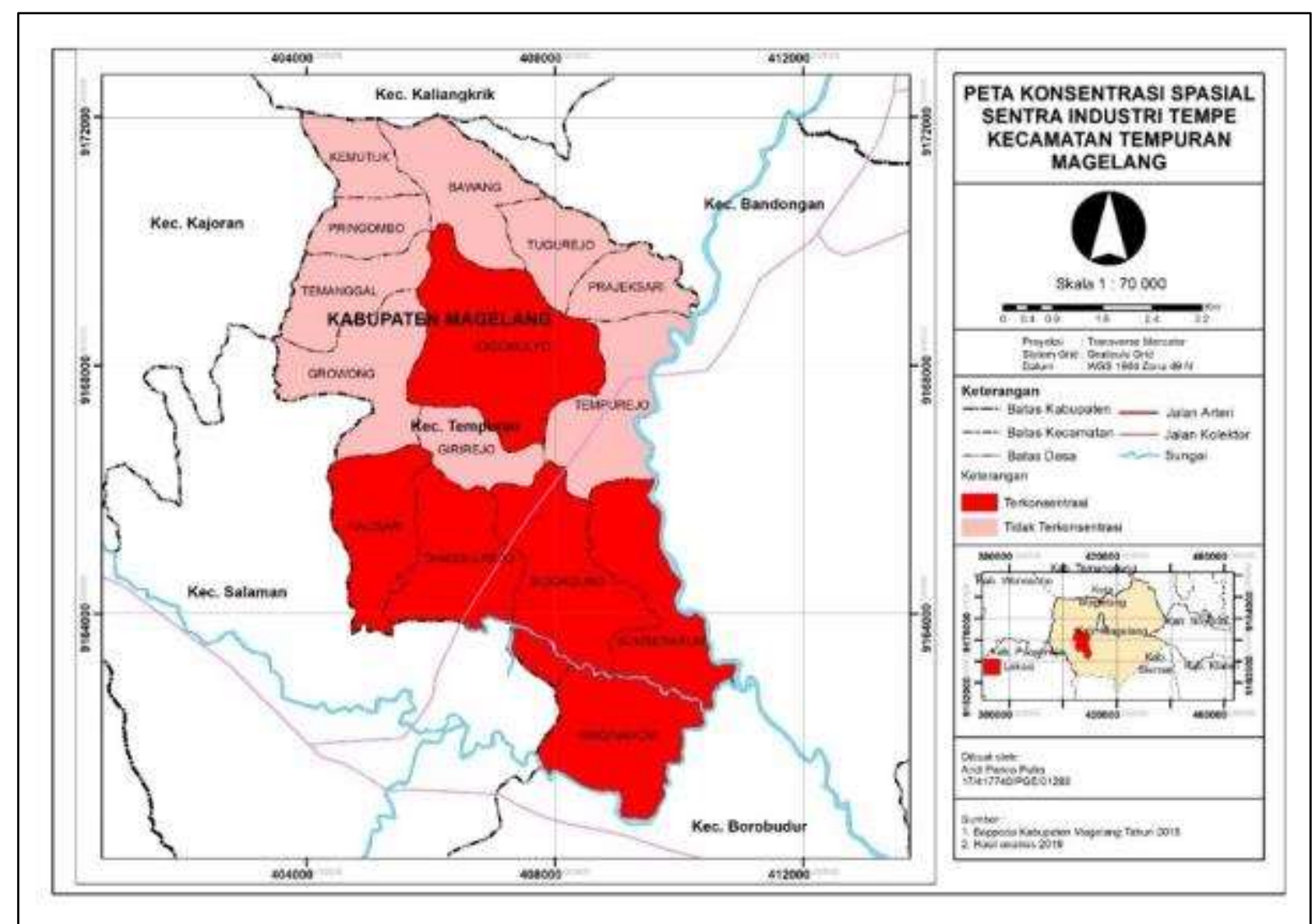

Gambar 1. Peta Konsentrasi Spasial Sentra Industri Tempe 
Nilai konsentrasi berkisar antara nol dan satu, semakin tinggi nilai konsentrasi maka sentra industri pada jenis tertentu cenderung terkonsentrasi pada wilayah tersebut dan pada peta semakin tinggi nilai maka warna pada peta akan semakin kontras, berdasarkan hasil pemetaan pada Gambar 1, terdapat enam desa yang menunjukan terkonsentrasi secara spasial yakni, Desa Jogomulyo dan Desa Kalisari, desa Tanggulrejo, Desa
Sidoagung, Desa Sumberarum dan Desa Ringianom, dengan sentra industri tempe yang terkonsentrasi secara spasial dilihat dari jumlah pangsa tenaga kerja dan unit jumlah industri yang terdapat di desa. Dengan demikian adanya pengelompokan industri tempe di beberapa desa di Kecamatan Tempuran dapat memberikan peluang yang lebih besar terhadap pangsa tenaga kerja di Kecamatan Tempuran itu sendiri.

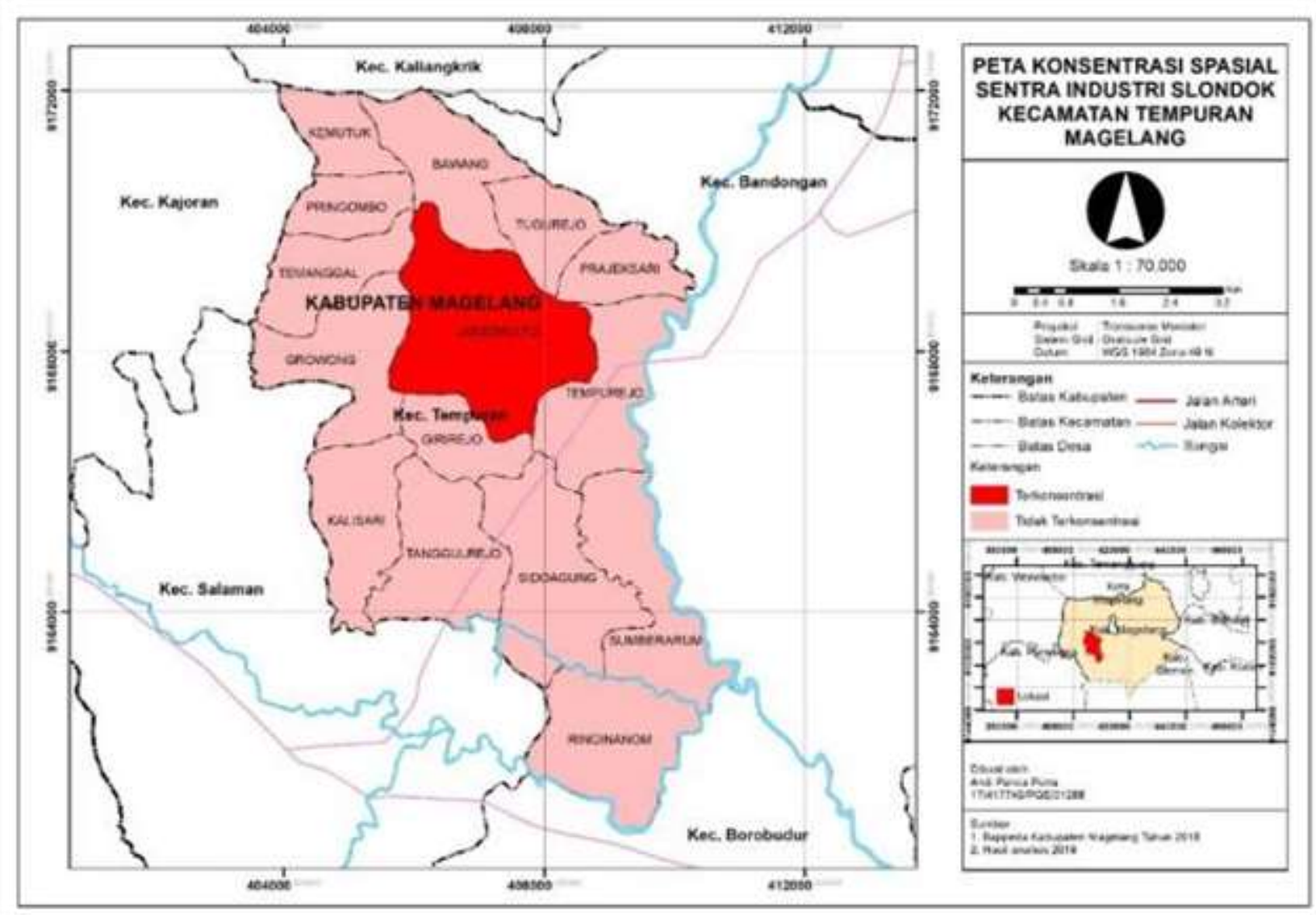

Gambar 2. Peta Konsentrasi Spasial Sentra Industri Slondok

Nilai konsentrasi berkisar antara nol dan satu, semakin tinggi nilai konsentrasi maka sentra industri pada jenis tertentu cenderung terkonsentrasi pada wilayah tersebut dan pada peta semakin tinggi nilai maka warna pada peta akan semakin kontras, berdasarkan hasil pemetaan pada Gambar 2, terdapat satu desa yang menunjukan terkonsentrasi secara spasial yakni, Desa Jogomulyo dengan sentra industri slondok yang terkonsentrasi secara spasial dilihat dari jumlah pangsa tenaga kerja dan unit jumlah industri yang terdapat di desa. Dengan demikian adanya pengelompokan industri slondok di beberapa desa di Kecamatan Tempuran dapat memberikan peluang yang lebih besar terhadap pangsa tenaga kerja di Kecamatan Tempuran itu sendiri. 


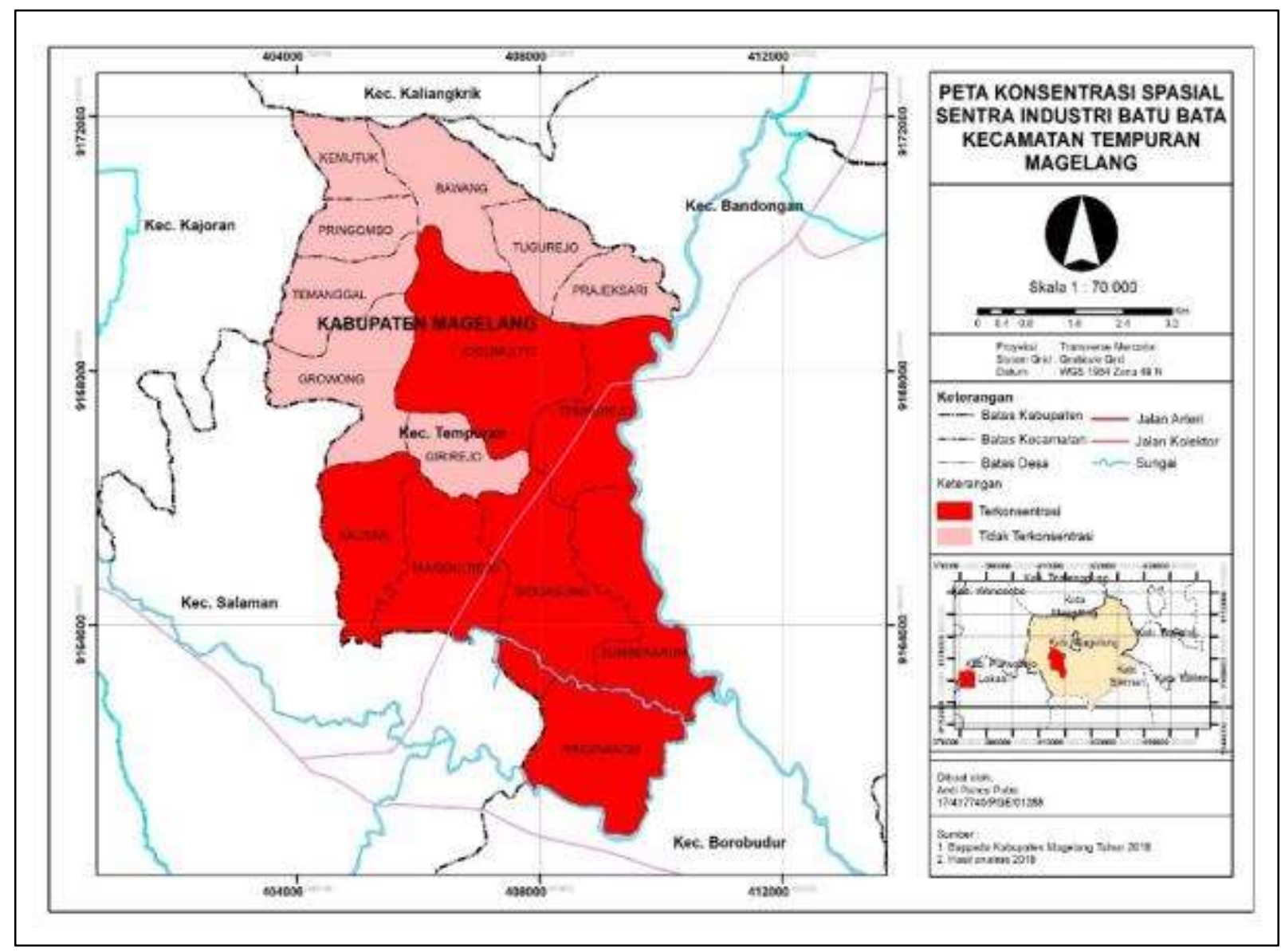

Gambar 3. Peta Konsentrasi Spasial Sentra Batu Bata.

Nilai konsentrasi berkisar antara nol dan satu, semakin tinggi nilai konsentrasi maka sentra industri pada jenis tertentu cenderung terkonsentrasi pada wilayah tersebut dan pada peta semakin tinggi nilai maka warna pada peta akan semakin kontras, berdasarkan hasil pemetaan pada Gambar 3, terdapat tujuh desa yang menunjukan terkonsentrasi secara spasial yakni, Desa Jogomulyo, Desa Tempurejo, Desa Kalisari, Desa Tanggul Rejo, Desa Sidoagung, Desa Sumberarum dan Desa Ringinom dengan sentra industri batu bata yang terkonsentrasi secara spasial dilihat dari jumlah pangsa tenaga kerja dan unit jumlah industri di desa. dengan demikian adanya pengelompokan industri batu bata di beberapa desa di Kecamatan Tempuran dapat memberikan peluang yang lebih besar terhadap pangsa tenaga kerja di Kecamatan Tempuran.
Nilai konsentrasi berkisar antara nol dan satu, semakin tinggi nilai konsentrasi maka sentra industri pada jenis tertentu cenderung terkonsentrasi pada wilayah tersebut dan pada peta semakin tinggi nilai maka warna pada peta akan semakin kontras, berdasarkan hasil pemetaan pada Gambar 4, terdapat tiga desa yang menunjukan adanya konsentrasi industri secara spasial yakni, Desa Temanggal, Desa Girirejo dan Desa Ringinonm. Industri yang terkonsentrasi adalah sentra industri mebel Kayu terkonsentrasi secara spasial dilihat dari jumlah pangsa tenaga kerja dan unit jumlah industri yang terdapat di desa. dengan demikian adanya pengelompokan industri Mebel Kayu di beberapa desa di kecamatan Tempuran dapat memberikan peluang yang lebih besar terhadap pangsa tenaga kerja di Kecamatan Tempuran seperti terlihat pada Gambar 4. 


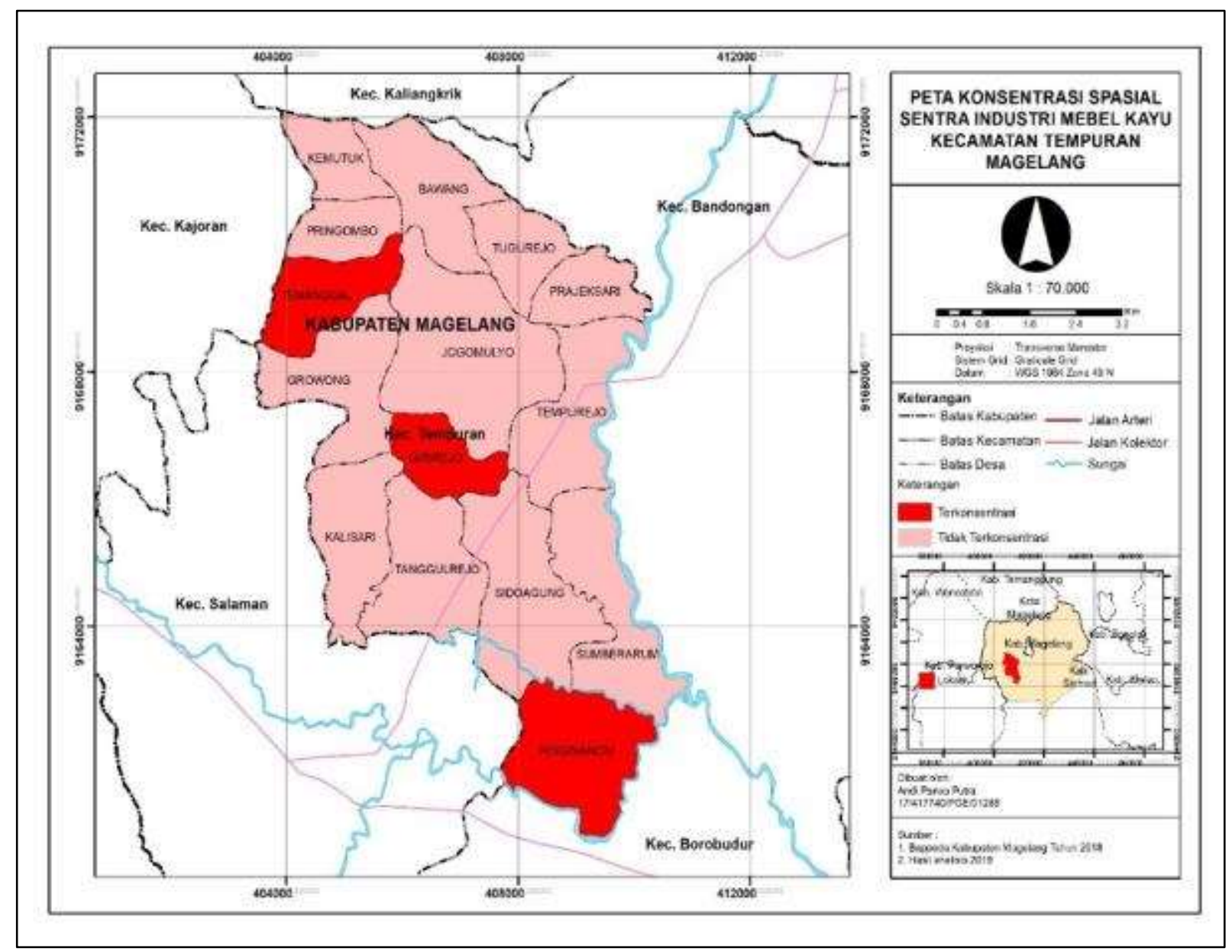

Gambar 4. Peta Konsentrasi Spasial Sentra Industri Mebel Kayu

Jika dilihat Nilai konsentrasi berkisar antara nol dan satu, semakin tinggi nilai konsentrasi maka sentra industri pada jenis tertentu cenderung terkonsentrasi pada wilayah tersebut dan pada peta semakin tinggi nilai maka warna pada peta akan semakin kontras, berdasarkan hasil pemetaan, terdapat tiga desa yang menunjukan terkonsentrasi secara spasial yakni, desa Tugurejo, desa Jogomulyo dan Tanggulrejo dengan sentra industri besek yang terkonsentrasi secara spasial dilihat dari jumlah pangsa tenaga kerja dan unit jumlah industri yang terdapat di desa. dengan demikian adanya pengelompokan industri Besek di beberapa desa di kecamatan Tempuran dapat memberikan peluang yang lebih besar terhadap pangsa tenaga kerja di Kecamatan Tempuran seperti terlihat pada Gambar 5.
Jika dilihat Nilai konsentrasi berkisar antara nol dan satu, semakin tinggi nilai konsentrasi maka sentra industri pada jenis tertentu cenderung terkonsentrasi pada wilayah tersebut dan pada peta semakin tinggi nilai maka warna pada peta akan semakin kontras, berdasarkan hasil pemetaan terdapat empat desa yang menunjukan terkonsentrasi secara spasial yakni, Desa Growong, Desa Kalisari, Desa Tanggulrejo dan Desa Sidoagung, dengan sentra industri Keranjang Tongkol dilihat dari jumlah pangsa tenaga kerja dan unit jumlah industri. Dengan demikian adanya pengelompokan industri Keranjang Tongkol di beberapa desa di Kecamatan Tempuran dapat memberikan peluang yang lebih besar terhadap pangsa tenaga kerja di Kecamatan Tempuran seperti terlihat pada Gambar 6. 
Pengembangan Sentra Industri Kecamatan Tempuran Berdasarkan Indeks Spesialisasi dan Konsentrasi Spasial di Kabupaten Magelang/ Andi Panca Putra, Andri Kurniawan, Sri Rahayu Budiani



Gambar 5. Peta Konsentrasi Spasial Sentra Industri Besek

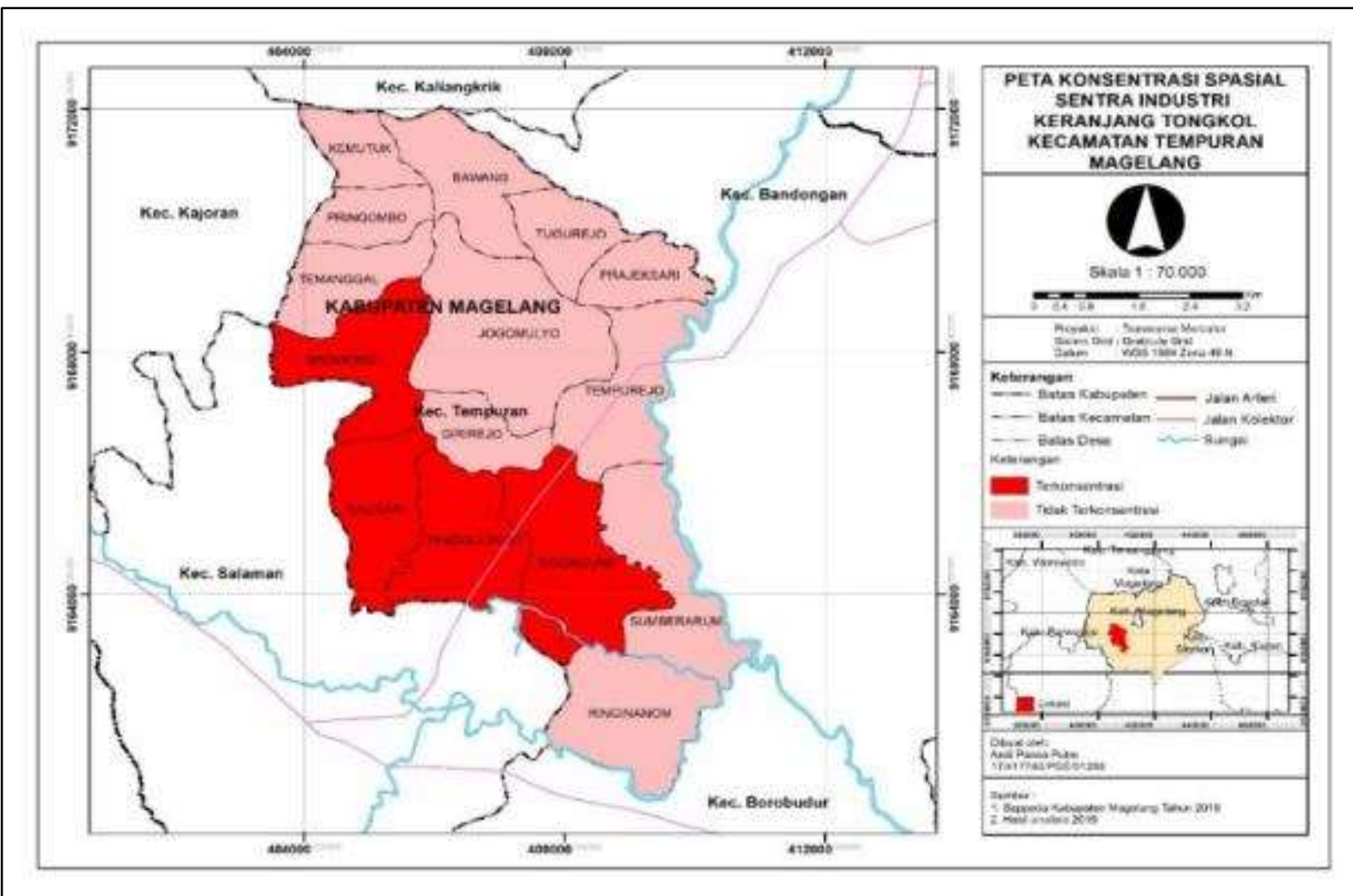

Gambar 6. Peta Konsentrasi Spasial Sentra Industri Keranjang Tongkol 
Jika dilihat Nilai konsentrasi berkisar antara nol dan satu, semakin tinggi nilai konsentrasi maka sentra industri pada jenis tertentu cenderung terkonsentrasi pada wilayah tersebut dan pada peta semakin tinggi nilai maka warna pada peta akan semakin kontras, berdasarkan hasil pemetaan terdapat tiga desa yang menunjukan terkonsentrasi secara spasial yakni, Desa Growong,
Desa Bawang, dan Desa Sidoagung dengan sentra industri kusen kayu dilihat dari jumlah pangsa tenaga kerja dan unit jumlah industri yang terdapat di desa. Dengan demikian adanya pengelompokan industri kusen kayu di beberapa desa di Kecamatan Tempuran dapat memberikan peluang yang lebih besar terhadap pangsa tenaga kerja di Kecamatan Tempuran seperti terlihat pada Gambar 7.

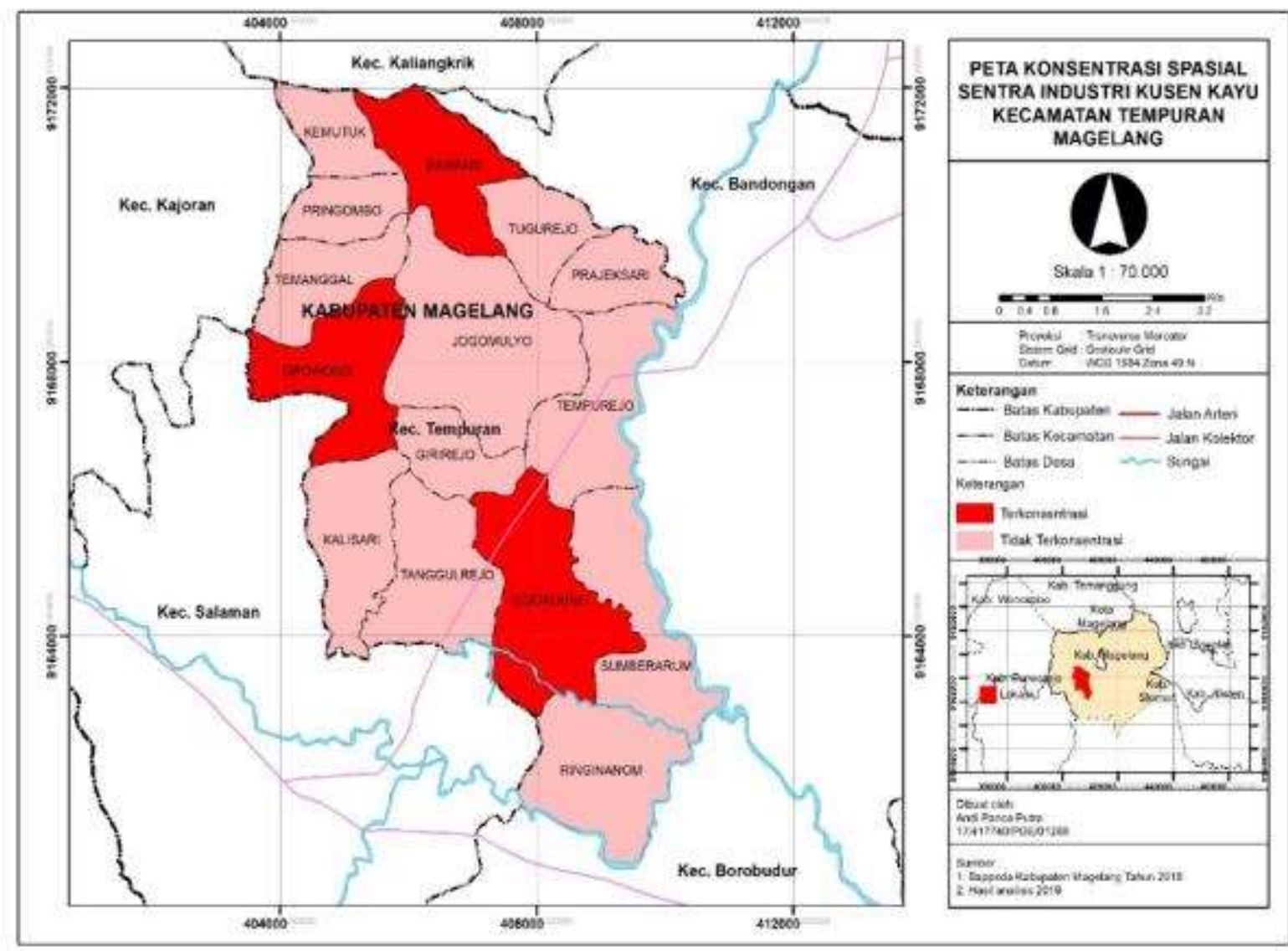

Gambar 7. Peta Konsentrasi Spasial Sentra Industri Kusen Kayu

Jika dilihat Nilai konsentrasi berkisar antara nol dan satu, semakin tinggi nilai konsentrasi maka sentra industri pada jenis tertentu cenderung terkonsentrasi pada wilayah tersebut dan pada peta semakin tinggi nilai maka warna pada peta akan semakin kontras, berdasarkan hasil pemetaan terdapat empat desa yang menunjukan terkonsentrasi secara spasial yakni, Desa Tugurejo, Desa Prajeksari, Desa
Tempurejo dan Desa Kalisari dengan sentra industri sangkar burung dilihat dari jumlah pangsa tenaga kerja dan unit jumlah industri yang terdapat di desa. dengan demikian adanya pengelompokan industri sangkar burung di beberapa desa di Kecamatan Tempuran dapat memberikan peluang yang lebih besar terhadap pangsa tenaga kerja di Kecamatan Tempuran seperti terlihat pada Gambar 8. 
Pengembangan Sentra Industri Kecamatan Tempuran Berdasarkan Indeks Spesialisasi dan Konsentrasi Spasial di Kabupaten Magelang/ Andi Panca Putra, Andri Kurniawan, Sri Rahayu Budiani

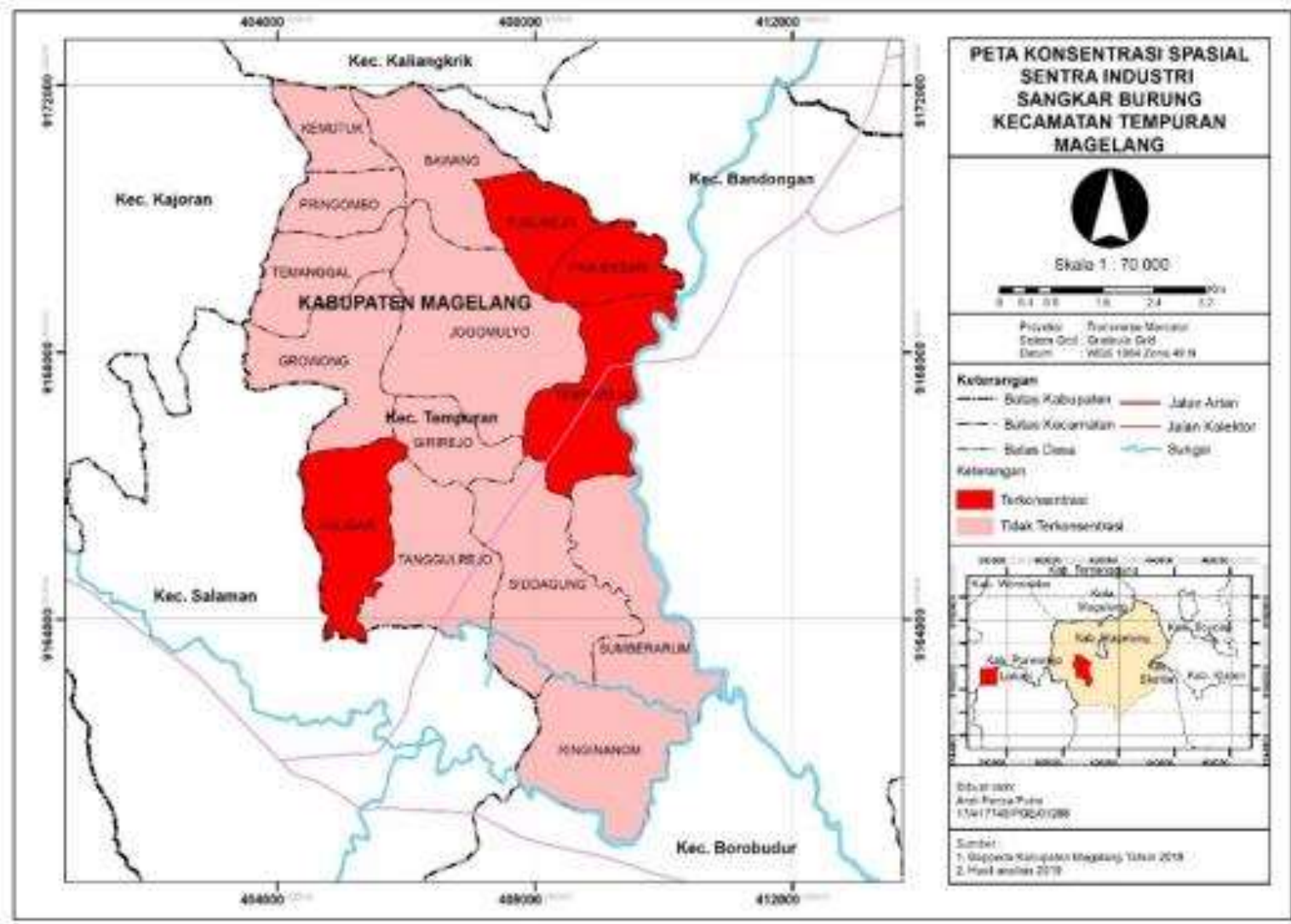

Gambar 8. Peta Konsentrasi Spasial Sentra Industri Sangkar Burung

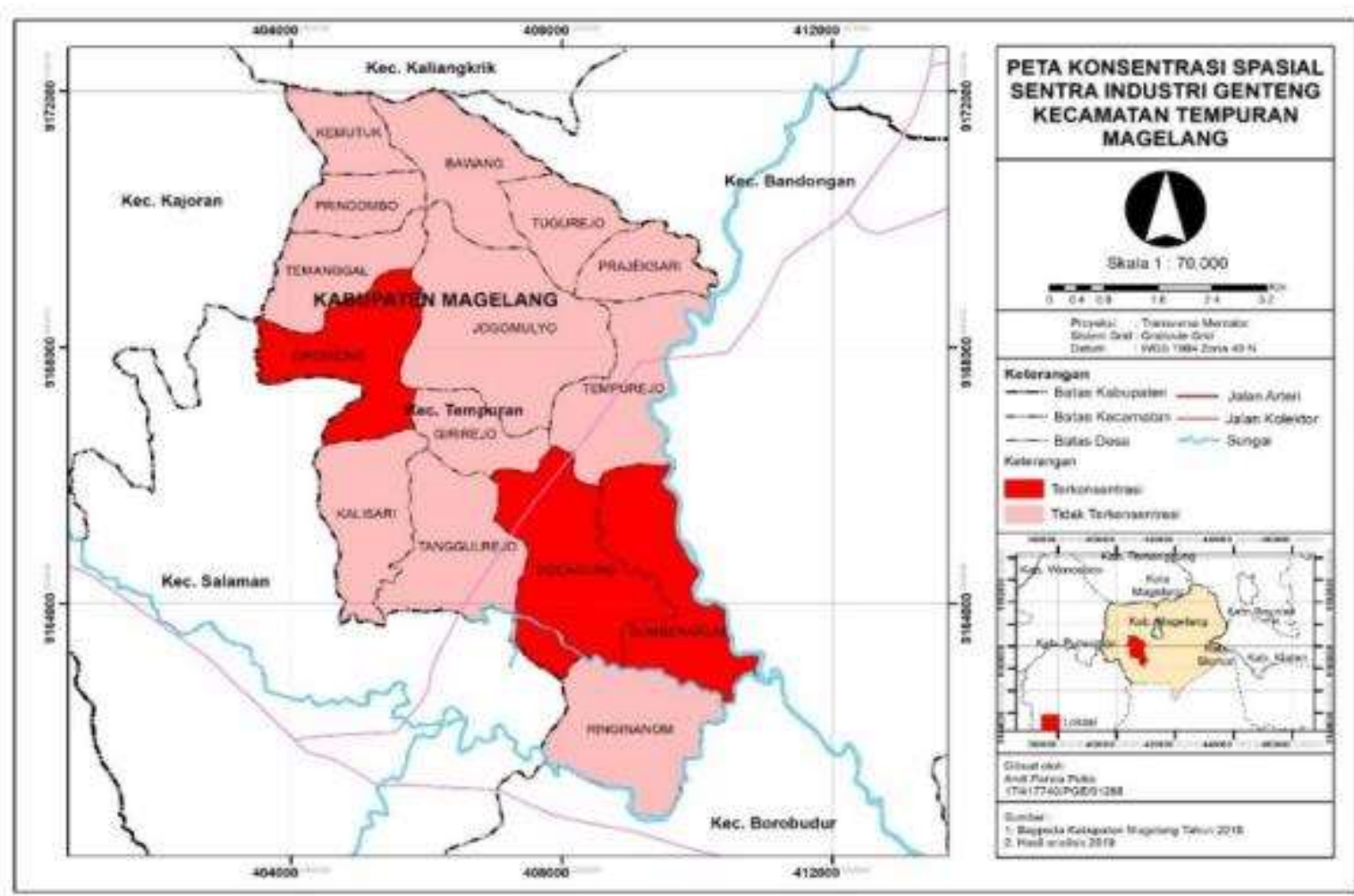

Gambar 9. Peta Konsentrasi Spasial Sentra Industri Genteng 
Pada sentra industri genteng yang terdapat di kecamatan Tempuran jika dilihat Nilai konsentrasi berkisar antara nol dan satu, semakin tinggi nilai konsentrasi maka sentra industri pada jenis tertentu cenderung terkonsentrasi pada wilayah tersebut dan pada peta semakin tinggi nilai maka warna pada peta akan semakin kontras. Berdasarkan hasil pemetaan pada Gambar 9, terdapat tiga desa yang menunjukan terkonsentrasi secara spasial yakni, Desa Growong, Desa Sidoagung dan Desa Sumberarum dengan sentra industri genteng dilihat dari jumlah pangsa tenaga kerja dan unit jumlah industri yang terdapat di desa. Dengan demikian adanya pengelompokan industri genteng di beberapa desa di Kecamatan Tempuran dapat memberikan peluang yang lebih besar terhadap pangsa tenaga kerja di Kecamatan Tempuran.

\section{Kesimpulan}

Berdasarkan hasil pengumpulan data dan analisis data dalam penelitian ini dapat dirumuskan beberapa kesimpulan. sentra industri yang menjadi spesialisasi di Kecamatan tempuran

yang memiliki nilai spsesialisasi terbesar pada sentra industri batu bata dengan nilai indeks spesialisasi sebesar 21,71 persen. selanjutnya di ikuti pada sentra ndustri sangkar burung dengan nilai indeks spesialisasi sebesar 13,44 persen.

sentra industri yang memiliki aglomerasi di atas 0,4375 yakni sentra industri dengan nilai $\mathrm{IHH}$ terbesar yang mendekati satu adalah sentra industri Kusen kayu, sentra industri sangkar burung, sentra industri tempe, sentra industri mebel kayu, sentra industri besek, sentra industri batu bata. sementara sentra industri yang dikategorikan dispersi yang memiliki Indeks $\mathrm{IHH}$ kurang dari 0,4375 terdapat tiga sentra industri yakni, sentra industri genteng, industri slondok dan sentra industri keranjang tongkol.
Berdasarkan kesimpulan dari hasil penelitian, maka temuan pada penelitian ini dapat memberikan gambaran mengenai kondisi keadaan sentra industri berdasarkan indeks spesialisasi dan konsentrasi spasial sentra industri. Hasil tersebut dapat digunakan sebagai bahan pertimbangan maupun masukan untuk pemerintah setempat dalam melakukan perencanaan, pendekatan, hingga pengembangan arahan kedepan bagi keberlanjutan sentra industri.

\section{Ucapan Terima Kasih}

ucapan terima kasih penulis sampaikan kepada Dr. Andri Kurniawan, M.Si. dan Dr.Sri Rahayu Budiani S.Si, M.Si yang telah membimbing dan memberi masukan dalam penyelesaian penelitian ini, serta segala pihak yang telah membantu penyelesaian penelitian ini.

\section{Daftar Pustaka}

Agustina, \& Rejekiningsih, T. W. (2011). Spesialisasi Dan Konsentrasi Spasial Industri Kecil Menengah Di Kota Semarang. Universitas Diponegoro.

BPS Kabupaten Magelang. (2018). Kabupaten Magelang dalam Angka 2018. Badan Pusat Statistik

Ferdyansyah, D., \& Santoso, E. B. (2013). Pola Spasial Kegiatan Industri Unggulan di Propinsi Jawa Timur (Studi Kasus: Subsektor Industri Tekstil, Barang Kulit, dan Alas Kaki). Jurnal Teknik ITS, 2(1), 37-42.

Krugman, P. (1991). Increasing Returns And Economic Geography. Journal Of Political Economy, 99(3), 483499.

Pridiatama, R., Kurniawan, A., \& Sudrajat. (2019). Karakteristik Dan Tipologi Industri Mikro, Kecil, Dan Menengah Agroindustri Apel Di Kota Batu. Media Komunikasi Geografi, 20(1), 44-55.

Ratnasari, A. (2013). Peranan Industri Kecil Menengah (IKM) Dalam Penyerapan Tenaga Kerja Di Kabupaten Ponorogo. Jurnal Pendidikan Ekonomi, 1(3), 71-80. 
Setiawan, I. R., \& Sudrajat. (2019). Analisis Pola Persebaran Lokasi Perdagangan dan Jasa di Kota Tebing Tinggi. Media Komunikasi Geografi, 20(1), 21-33.

Suhardi, B. (2010). Spesialisasi Dan Konsentrasi Spasial Industri TPT Di Kota Surakarta Dan Karanganyar. In Seminar Nasional Manajemen Teknologi XII. Yogyakarta: Universitas Gadjah Mada.

Sulastri, R. (2013). Konsentrasi Spasial Industri: Kajian Empirik di Indonesia. Jurnal Polibisnis, 5(1), 35-44.

Triamita, L. (2012). Jurnal Analisis Konsentrasi Regional Tenaga Kerja Usaha Kecil dan Menengah (UKM) Kabupaten/Kota di Jawa Timur (Tahun 2004-2010). Jurnal Ilmiah Mahasiswa FRB, 1(2), 71-80.

Whynne, C., \& Hammond. (1979). Elements of Human Geography. London: George Allen \& Unwin. 